\title{
The Visual Archive: the self as author and actor
}

\begin{abstract}
This article intends to discuss how in some contemporary photography, the author participates as character of the work (as much as he reveals himself or the character that embodies him) and which metamorphoses take place in this photographic narrative. The work of the British twins Jane and Louise Wilson, specifically the video Hypnotic Suggestion 505, made in Portugal for the Walter Benjamin's Briefcase (1993) exhibition from the curator Andrew Renton in Oporto and the works Oddments Room (2008-09) and Unfolding The Aryan Papers (2009) will be analyzed. Starting from the ambiguity of the construction of the author and character in Roland Barthes by Roland Barthes (1975), the understanding of how much is shown and hidden through this fragmentary writing is sought. According to John Roberts, in the essay Photography after the Photograph (2009), the critique of photography assumed a Barthesian discourse, where photography in a public context (magazines) or in an instrumental context (technical publications) was not exempt of a discursive montage and therefore there would not be transparency in the image.

These works by Jane and Louise Wilson represent a discourse of visual archive where the authors use real spaces and facts as motto, assuming themselves as characters.
\end{abstract}

\author{
Maria João Baltazar. \\ ESAD College of Art and Design, \\ Portugal. \\ baltazarmariajoao@gmail.com
}

\section{Fátima Pombo.}

Department of Architecture, University of Leuven, Belgium. fatima.teixeirapombo@asro. kuleuven.be

\section{Recibido: Octubre 2014 Aprobado: Abril 2015 \\ Key words: \\ Photography, staging, identity, character, document}

What was once inherent to the photographic medium -the documental value of the record without mise en scène- is now redefined through a subtle articulation between public domain and private space.

This essay aims to contribute to the critique of contemporary photograph, namely for an actual redefinition of the documental value of the moment of photographic record.

Revista KEPES Año 12 No. 11 enero-junio 2015, págs. 83-97 ISSN: 1794-7111(Impreso) ISSN: 2462-8115 (En línea) DOI: $10.17151 /$ kepes.2015.12.11.5 


\section{O Arquivo Visual: o eu como autor e ator}

\section{Resumo}

Com este texto pretendemos discutir de que modo em certa fotografia contemporânea o autor se assume como personagem da obra (quanto revela de si e do personagem que corporifica) e que metamorfoses se dão nessa narrativa fotográfica. Para isso, analisaremos a obra das gémeas britânicas Jane e Louise Wilson, especificamente o vídeo Hypnotic Suggestion 505, realizado em Portugal para a exposição A Pasta de Walter Benjamin (1993) do curador Andrew Renton, e no espaço da Fábrica de Moagens Harmonia no Porto e, recentemente, as obras Oddments Room (2008-09) e Unfolding The Aryan Papers (2009).

Partindo da ambiguidade da construção do personagem e do autor em Roland Barthes por Roland Barthes (1975), procuraremos compreender quanto se mostra e se oculta através dessa escrita fragmentária. De acordo com John Roberts no artigo Photography after the Photograph (2009), a

Palavras-chave:

Fotografia, encenação, identidade, personagem, documento. crítica da fotografia assumiu um discurso barthesiano segundo o qual a fotografia no âmbito de um contexto público (revistas), ou no âmbito de um contexto instrumental (publicações técnicas) não estaria isenta de uma montagem discursiva o que impossibilitaria a transparência da imagem.

Estas obras de Jane e Louise Wilson corporificam um discurso visual arquivístico onde as autoras tomam como mote factos e espaços reais e a partir dos quais se assumem como personagens.

O que outrora fora ínsito ao meio fotográfico — o valor documental do registo sem mise en scène — é hoje redefinido através de uma subtil articulação entre contexto público e espaço privado.

Este artigo procura contribuir para o discurso crítico da fotografia contemporânea, nomeadamente, para a actual redefinição do valor documental do registo fotográfico. 


\section{Barthes's ambiguous identity construction}

At the start of Roland Barthes par Roland Barthes, the narrator ${ }^{1}$ points out that the images gathered in this work are the ones that disturbed and fascinated him without knowing exactly why. This collection of images, ranging from the late 19th century and 1974, comprises a set of family photographs and documents, postcards, photographs of conferences, reproductions of manuscripts, worksheets and a sheet of music, color markers, and a few photographs by Daniel Boudinet. Upon completing his book, the author offered himself the "selfish pleasure" of this selection and montage of images (Barthes, 2002, p. 581). Barthes describes for us how the photographic portrait stirs in him a feeling of torture and enchantment, images which, though not resembling him - details featuring teeth, hair, nose, thinness, legs with long socks- do not pertain to anyone else, either:

\footnotetext{
What fascinates me about these photographs, therefore, is not the nostalgia of a happy time, but, rather, something more indefinite. [...] it torments itself and is enchanted with a vision that is in no way morphological (it never resembles me), but, rather, organic. [...] here I am, thus, in a state of disquieting familiarity: I see the entrails of the man (that which we cannot talk about). Hence, we can conclude that the photograph of one's youth is, at the same time, very indiscrete (it is the hidden side of my body that is revealed) and very discrete (it's not talking about me). (Barthes, 2002, pp. 581-582)
}

The photograph's difficulty in setting its identity and, on the other hand, the acknowledgment of its physical traits in any portrait, are closer to a discursive fragmentation process that is also typical of Barthesian works. The presentation of sudden details inconclusively announcing a discourse, short writing through fragments, resembles analog photo capturing, frameworks chosen and set by the photographer. By adding small portions, fragmented writing intensifies each entry, the same way the photographer, by accumulating various records, intensifies his observation at the moment when he takes the photograph, and at the moment when he selects contact proofs. This way, reading the Barthesian text leads us to perceive a dual fragmentation process, through writing and photography, as a particular way of recording decisive moments (Cartier-Bresson, 1999, pp. 20-43).

${ }^{1}$ Throughout the work, the narrator refers to the author using the pronouns "he" and " $\mathrm{I}$ ", thereby giving rise to an ambiguity and overlapping of Barthes-narrator and Barthes-author. 
Between the 1930s and the 1950s, street photography (Scott, 2007) undertaken by the street photographer using a Leica and black-and-white film matched the theoretical and practical assumptions upheld by Henri Cartier-Bresson, which became world renowned through the American edition of The Decisive Moment (1952).

To me, photography is the simultaneous recognition, in a fraction of a second, of the significance of an event as well as of a precise organization of forms which give that event its proper expression. (CartierBresson, 1999, p. 42)

The photographer must reject any manipulation of reality, both when taking the picture and from the laboratory work carried out. Setting reality, or Things-As-TheyAre, insofar as a moment in life is selected and captured, to which we can never return. The portrait photograph also appears to enhance the transience of that moment, as experienced by the photographer and the subject being portrayed, due to the very transience of the human facial expression. The weight of photography (Barthes, 2010, p. 27), a sign that always carries its significance, highlights a stubborn motionlessness, unlike a subject's living image. The photographic countenance makes the portrayed subject part of a description, a classification or taxonomy.

Barthes ambiguously places himself relative to Cartier-Bresson's assumptions. Whereas the latter puts forth the possibility of overlapping the value of evidence found in the decisive moment and the truth of the subject, as set through its photographic portrait, Barthes switches between the photographic evidence and photographic discourse regarding its subjective relation with a given photograph. On one hand, the inevitability of photographer and the subject being photographed having been there, that is, at that moment and location which match the photograph's noema 'Ça-a-été' (Barthes, 2010, p. 120) and, on the other, the narrative regarding the Photographie du Jardin d'Hiver, dated 1898, where he finds the essence of his mother. This overlapping of the documented valor of the photographic portrayal and the psychological value of the subject being portrayed conceives the notion that analog photography can carry with it the reference itself, that is, that the reference holds fast to the depiction. 


\section{The analog photographic portrayal and temporality of the image}

The Barthesian switch between the documented and historical value and the personal and subjective value of the photographic portrayal has characterized the theory of photography as early as the 1980s: Nancy M. Shawcross, Jean-Michel Rabaté, Diana Knight, and Geoffrey Batchen published significant works ${ }^{2}$ on the theory of photography after analyzing La Chambre claire.

The historical and esthetic modernity of the photographic medium, ${ }^{3}$ constructed between 1839 and the 1950s, characterized photography as a process of capturing and reproducing that which is real, using various scientific, anthropological and reporting applications. These discursive and disciplinary applications combined with the work of the photographer-author that captured daily life and truth. The technical domain of the photographic medium in black and white, while capturing the unrepeatable framework, where everyday triviality was harmoniously composed and refined, essentially became the theoretical and practical assumptions of that modern photographer

Throughout the latter half of the 20th century, the documental value of photography, as well as European and American formalism linked to Alexander Gardner, Alfred Stieglitz, Lewis W. Hine, August Sander, André Kertész, or William Klein, ${ }^{4}$ were being redefined by authors who were more interested in the discursive content of the photographic medium. Robert Frank, Lee Friedlander, Christian Boltanski, Allan Sekula, Sophie Calle, Cindy Sherman, or Joan Fontcuberta developed photographic series, artist books, and texts that dealt with the photographic medium through theoretical questioning. The process of photographic image signification became intersubjective: unlike setting a truth or an artistic canon in it, what was reaffirmed

\footnotetext{
${ }^{2}$ Shawcross (1996), Rabaté (1997), Knight (2000), Batchen (2009).

${ }^{3}$ The documental nature of photography was prominent for constructing the history and theory of this means of depiction, from its origins to its modern maturity. We refer to the origin and maturity of modern photography, considering the discourse presented in 1839 by François Arago to the Members of the House of Representatives, and the late 1950s, as from the American publication, in 1952, of the work The Decisive Moment by Cartier-Bresson. With regard to the modernity of photography, see Phillips (1989).

${ }^{4}$ These are all photographers whom we associate with a discourse and a practice we called modern: war photography, photojournalism and capturing life in an industrial city, or in a post-war city, from the 1850s to the 1950s. Martin Parr and Gerry Badger characterize photographic modernity from the following themes: Facing Facts, Photo Eye, A Day in the Life, Memory and Reconstruction (Parr \& Badger, 2004). It is also significant that the photographs Roland Barthes selected for La Chambre Claire include photographs by all these photographers.
} 
was the value of a signification process perceived to be dependent on the image's historic and cultural context.

At the end of La Chambre claire, Roland Barthes announced a demise for Photography -Barthes capitalized this last word to refer to analog photography- with an analog portrayal, to which it was linked by taste and generation. The bipolar confrontation between the photograph's documental value (studium) and its subjective value (punctum), echoed the historical and cultural confrontation of the photographic medium between technical operability and artistic process, as well as between identity-related truth and imperfect countenance. Whereas the document, the mechanics of the camera, and the photograph as a descriptive portrayal and setting of that which is real were associated with studium, subjectivity, artistic production, and the shift from the subject to the photograph were linked to punctum.

In order for the photographic image to detach themselves from this genetic confrontation -what we consider to be significant when upholding the argument below, from the work by Jane and Louise Wilson- we would need, on the one hand, a selflessness by the subject with regard to the truth of its portrait from analog Photography and, on the other, the development of a more conceptual discourse and practice of the photographic medium where the temporality of the image is asserted.

\section{Jane and Louise Wilson's image and language}

In 1993, British twins Jane and Louise Wilson directed a video, entitled Hypnotic Suggestion 505, at the decommissioned Fábrica de Moagens Harmonia factory, in Porto, Portugal. One of the first video works by the Wilson twins (whose work is highlighted by photographic series, video facilities, three-dimensional structures, and an interest by architectural landmarks in ruins), it stresses the topic of identity- and truth-related ambiguity in the film recording. Both sisters, then 26, dressed alike and identical in all things, underwent two hypnosis sessions, one of which was 
conducted by a Portuguese national and other by an Englishman. They are roused from their deep sleep and brought back to consciousness is the sentence, 'When I say 505, you will open your eyes'. The authors' identity-related reproduction, the duplicating of the hypnosis sessions, and duplication of the reading found in the palindromic number 505, cause the spectator to hearken to some blurring. If the work's mise-en-scène is basically the blue curtain, the stage with the two chairs where Jane and Louise are seated and the tension generated between them and the hypnotists, this physical stripping is also associated with the video montage. Thus, the spectator perceives two levels of significance which are decisive in this work: on the one hand, some blurring regarding space and time, insofar as the plans and the video montage allow the spectator to draw either closer or further away from the actual location and time, and, on the other hand, the formal stripping when dealing with a film document, unlike a fictional work, causes the spectator to hearken to the truth of the recording.

The significance of the work by the Wilsons, as part of the contemporary artistic landscape, their interest in the confrontation between the documental value of the photographic portrayal and the film recording associated with a mise-en-scène of the architectural space as historical ruins, originated in 2010, with the Calouste Gulbenkian Foundation's Center of Modern Art, in Lisbon, showcasing the biggest individual exhibit by these artists. Suspending Time (Carlos \& Cousins, 2010), whose curator was Isabel Carlos, highlighted a current understanding of the historical value of architectural landmarks -World War II-era bunkers shown in the series Sealander (2006), the brutalist architectural structures, or the Stanley Kubrick archive that gave rise to Unfolding the Aryan Papers (2009).

Montage, fragment and documental mise-en-scène, are all significance-building strategies that the Wilsons also use in Oddments Rooms (2008-09) and Unfolding the Aryan Papers. 
In corridors and doors linking rooms of used bookstores, whose walls are covered with various volumes, we see a female figure standing with her back turned. In Oddments Rooms, Louise Wilson plays that elegant, high-heeled woman wearing a silk dress and her hair tied back. However, the documental and commercial value, as well as the rarity associated with the old book, are called into question, as the volumes in these rooms are incomplete objects whose cover or a page are missing. This flaw, in this case due to the lack of a fragment, pertains to the very erosion of time, the precariousness of the historical document which is necessarily dependent on a preservation involving the construction of an archive and, therefore, the act of suspending the course of history itself.

In this respect, the vitality the analog photographic portrait seeks to achieve, the attempt to preserve life by suspending the necessary death of the portrayed individual and that of the portrait's observer, is linked to the preservation of the document, to this need to remove its daily functionality, by assigning it a symbolic historical value. Giuliana Bruno performs an analysis of $A$ Free and Anonymous Monument (2003), by the Wilsons, and from which an archeology of the film image is associated with the ruins of the architectural space.

As we live in an age in so many ways repelled by ruination, what kind of archaeology can we now create? In answering this question, we can take one last look at Jane and Louise Wilson's archaeology, and ponder in yet one more way their fascination with postindustrial ruins. We should recognize that our history is made up of different ruins. [...] Time passing is not simply etched on the surface of stone, but is marked on the skin of celluloid. [...] Moving images are modernity's ruins. (Bruno, 2007, p. 82)

A specific and relevant procedural sense since the 1970s, where communication casts aside the importance assigned to setting the image and to setting the sense of the project, while turning to a tensional and participative process, which emerges today as temporal exposure and experience. In the contemporary world, the project-related structure needed for building a communicative experience appears to imply a growing link between space and time, as specific elements for reflecting 
on the human being. The cultural production process, spanning across the entire spectrum of art, would draw away from the mere physical object and move closer to a communicative process that reintegrates two elements deriving from architecture and cinema: space and time through the human being's experiences, that is, via the mise-en-scène. The communicative process and emotional links initiated in the project, extend between the house and society, would no longer be unsuspecting in the project's description; the latter would also embody a symbiosis between space and time experienced by the subject, thus causing the work to make sense.

The contemporary world has shown awareness to various media, where depiction is not found. The broadening and blending of project-related processes which used to be solely associated with the evidence and tangibility of material production, depiction processes that are methodologically characterized by linking place and temporal duration With the 1970s, this contingent tends to be part of the project. A communicative process where valuing the moment and the setting of the modern framework becomes the valuation of a contingency of temporality of the image and of the experience in the surrounding space.

As for the documental value of photography in the contemporary world, John Roberts revisits this in his essay Photography after the Photograph: Event, Archive, and the Non-Symbolic (2009). A historical stereotype and of the analog photographic practice that had considered the value of the photographic portrayal from the instantaneousness of a captured occurrence, or event, today is redefined according to a delay in the photographic image, insofar as the event is now captured in its aftermath. Thus, this need to rearticulate the documental value of the photographic image is the assertion of a delay in the photographic image.

Gone is the notion of the photograph as an act of interruption, displacement, interrogation, rearticulation - of generalised movement and cognitive disruption: the avant-garde language of denaturalisation - to be replaced by the photograph as a site of "glacial" contemplation, as if the splendour and beauty of Ansel Adams' Yosemite pictures was the only available model for a workable and satisfying 
account of the event. [...] photography - the work seems to be saying - is at its most perspicacious and relevant when it foregrounds its mordant and memorial role. [...] This is why it is harder these days to distinguish photojournalism and documentary practice from the artistic appropriation of the photodocument, because both sets of practices are increasingly reliant on this circumscribed notion of the event-as-aftermath. (Roberts, 2009, pp. 292-293)

Unfolding the Aryan Papers, started off with images, documents and records from the archive of Stanley Kubrick, who sought to make a movie adaptation of Wartime Lies, by Louis Begley. The Aryan Papers, a movie about the Holocaust which was never made, and whose main character would have been played by Dutch actress Johanna ter Steege was, however, prepared over eight months' worth of investigations, photographic records, film footages and the choice of filming locations. During that period, Johanna worked closely with Kubrick, as she put herself in the character's shoes while awaiting the performance that could have marked her acting career. She was deeply frustrated over the project's cancellation.

Jane and Louise Wilson rearticulated Kubrick's project, starting from a temporal deployment: photographic and documental material, the writings and the work Wartime Lies, all of which served as the groundwork for the various objects pertaining to the history of a project not brought about, were now linked to new photographic, documental and movie records, where Johanna once again held the leading role.

Starting by scenically and formally stripping the architectural space to make it resemble the interior of the Hornsey Town Hall building, where the actress was registered by Kubrick, Johanna would also be registered by the Wilsons. Overlapping and return: on one hand, the formal influence of the choices made by the filmmaker -the character's, static pose, a blank stare--, which is repeated in the Wilsons' work, as well as the actress' return to those spaces, poses, and to a context of her past. Both the actress and the character undergo a metamorphosis, by overlapping Johanna and Kubrick's character as well as Johanna and the Wilsons' character. Still, the overlapping of the documental value also takes place, insofar 
as the items from Kubrick's archive, documents representing the film's building process (making it possible to distinguish between document and fiction of the film's narrative), are now dragged into Unfolding the Aryan Papers, where Johanna becomes both actress and character at the same time.

This convergence of actress and character, a deployment which drags reality and daily living to the fictional realm allows the spectator to identify with that Johannacharacter.

\section{The private domain constructed by the document}

In this text, from Barthes and that which called the modern photographer, we have mentioned a historical and cultural discourse of the photographic portrayal that brought about the paradigm of the photograph's crudity, its evidence-related nature, in contrast with the subject's psychological sketch, perceived as its true identity.

The subject's inability to see himself in the countenance of his photographic portrait and, on the other hand, the possibility that society will identify the subject just by looking at the photograph, amount to the construction of the private space and the public space.

Jane and Louise Wilson are two contemporary creators whose work constitutes a passage or deployment between these two domains, the private space and the public space, from evidence documented in photographs and on film. This deployment becomes pivotal for critically understanding the documental and identityrelated value of the photographic image in our contemporary world. When the Wilsons examine Stanley Kubrick's investigative material archive for the project The Aryan Papers, which never got off the ground, and extend it from a video setup, simultaneously bringing together archive items with new film recordings of actress Johanna ter Steege in that same narrative context, they carry out a subtle overlap- 
ping between the actress and the character, between the documented history of a fictional story that was never brought about, and a (hi)story where Johanna ter Steege plays Johanna ter Steege. This overlapping leads spectators to identify with that character, as the divide that once separated the misfortune of a given character from the glamour of the actress that played her (thereby leading them to converge on that misfortune and to envy the actress' life) is now suspended, insofar as the actress here is an unknown whose misfortune is her own life.

The photographic image today is shown to be distant from the impatience that characterized the age of analog Photography -the age of occurrences, of the instantaneous, of the sudden break, and of the decisive event-, in a deployment of the documental value that means a mise-en-scène based on a historical document, thereby bringing about a convergence and an identification on the part of the spectator.

This is precisely where we need to focus our attention, on the fact that the contemporary image brings about a display of space and time, by causing image-capturing, processing and reception procedures to be significant. The diversity of strategies developed does not favor the mere image construction and setting, but, rather, a significant interest in depictive temporality, thus returning the author to the density of life. The flow of daily events and the way they are consciously and emotionally experienced make it necessary to understand how the image oscillates. Regardless of the means or the operative strategy used, it will become necessary to overcome the inevitability of a definitive framework and a closed narrative.

If, today, there is a tacit agreement between the artist and the spectator as to the value of and interest in the device involving the enunciation of the work, the context in which it is developed and presented, the same does not occur when we observe an image, as we often forget that this is an element in a given presentation structure. Behind the depiction we are allowed to see, there is a concrete 
expository context and a context of signification, both at the same time, whereby the project is presented and grasped. With the development of a modern visual culture, the visual observation of the depiction was favored at the expense of its contextual dimension. Throughout the first half of the 20th century, the presence and reception of photography in various expository contexts -among them, the salon, trade show, store, museum or publication-, amounted to a heightened interest in the exposure of the unique image, apparently devoid of tangibility, while moving the understanding of the current presentations was left on the back burner. We are heirs of a condoning of image exposure; this means that we learn to forget or dismiss its enunciation: anything concrete that comprises the work and the whole of which it is a part, the support and the means whereby it comes unto us in considering a given expository context and, more profoundly, its permeability in conveying established meanings. However, this is precisely the pragmatic aspect of the work's expository presentation, along with the interchangeability of meanings when it is received; this has been the worked on by the depiction of the contemporary world as a mise-en-scène or enunciation value. The work is also found in that which groups the elements comprising it, as they are defined by the relation forged among themselves and according to the experience at that moment. That's akin to saying that the development of visual depiction has been interested in the way each element is organized in a concrete presentation but also in a presentation of sense, even though the author may understand that dual contingency. Works such as those by Jane and Louise Wilson prolong the legacies of modern visual culture, by reconsidering a look at the world that used to be defined as the moment and the camera's operative superiority, thus giving way to image oscillation, a reconfiguration process as a way of grasping a communicative truth. The project no longer shows the reference as being limited to an operative exposure, but, rather, evocations among various images and legacies; this means the quantification of that which is visible has been surpassed by the qualitative value of the work's enunciation. 


\section{References}

Barthes, R. (2002). Roland Barthes par Roland Barthes. In: OEuvres complètes Tome IV 1972-1976 (pp. 575-771). Paris: Éditions du Seuil.

Cinéma, Gallimard.

. (2010). La Chambre claire (Note sur la photographie). Paris: Cahiers du

Batchen, G. (2009). Photography Degree Zero: Reflections on Roland Barthes's Camera Lucida. Cambridge, MA: The MIT Press.

Bruno, G. (2007). 2. Modernist Ruins, Filmic Archaeologies: Jane and Louise Wilson's A Free and Anonymous Monument. In: G. Bruno, Public Intimacy: Architecture and the Visual Arts (pp. 43-82). Cambridge, MA: The MIT Press.

Carlos, I., \& Cousins, M. (2010). Jane \& Louise Wilson: Suspending Time. Lisbon: The Calouste Gulbenkian Foundation.

Cartier-Bresson, H. (1999). The Mind's Eye: Writings on Photography and Photographers. New York: Aperture.

Knight, D. (Ed.). (2000). Critical Essays on Roland Barthes. New York: Hall.

Parr, M., \& Badger, G. (2004). The Photobook: A History volume I. London: Phaidon Press.

Phillips, C. (Ed.). (1989). Photography in the Modern Era. New York: The Metropolitan Museum of Art, Aperture. 
Rabaté, J.-M. (Ed.). (1997). Writing the Image after Roland Barthes. Philadelphia: University of Pennsylvania Press.

Roberts, J. (2009). Photography after the Photograph: Event, Archive, and the NonSymbolic. Oxford Art Journal, 32(2), 281-298.

Scott, C. (2007). Street Photography: From Atget to Cartier-Bresson. London, New York: I. B. Tauris.

Shawcross, N. M. (1996). Roland Barthes on Photography: The Critical Tradition in Perspective. Gainesville: University Press of Florida.

Cómo citar este artículo:

Baltazar, M. J., \& Pombo, F. (2015). The Visual Archive: the self as author and actor. Revista Kepes, 11, 83-97. 